\title{
PENERAPAN PROBLEM BASED LEARNING UNTUK MENINGKATKAN KEMAMPUAN PEMECAHAN MASALAH KONTEKSTUAL BAGI PESERTA DIDIK KELAS X-IPA SMA ISLAM HASYIM ASY'ARI BATU PADA MATERI SISTEM PERSAMAAN LINEAR TIGA VARIABEL
}

\author{
Mustangin $^{1}$, Abdul Halim Fathani ${ }^{2}$, Teguh Sugiharto ${ }^{3}$ \\ ${ }^{1,2}$ Program Studi Pendidikan Matematika, Universitas Islam Malang \\ ${ }^{3}$ SMA Islam Hasyim Asy'ari Batu \\ mustangin@unisma.ac.id ${ }^{1}$, fathani@unisma.ac.id ${ }^{2}, \underline{\text { teguhs@gmail.com }}$
}

\begin{abstract}
Abstrak
Penelitian ini bertujuan untuk meningkatkan kemampuan pemecahan masalah kontekstual peserta didik kelas X-IPA SMA Islam Hasyim Asyari Batu Tahun Pelajaran 2018/2019 melalui penerapan model pembelajaran Problem Based Learning (PBL). Jenis penelitian ini adalah Penelitian Tindakan Kelas (PTK) yang dilaksanakan dalam dua siklus dengan 2 kali pertemuan setiap siklusnya. Setiap siklus terdiri dari beberapa tahap yaitu perencanaan, pelaksanaan tindakan, observasi dan refleksi. Siklus pertama dan kedua membahas materi pokok sistem persamaan linear tiga variabel (SPLTV). Subjek dalam penelitian ini adalah peserta didik kelas X-IPA SMA Islam Hasyim Asyari Batu Tahun Pelajaran 2018/2019 yang terdiri atas 24 peserta didik. Hasil penelitian menunjukkan bahwa penerapan model pembelajaran Problem Based Learning (PBL) dapat meningkatkan kemampuan pemecahan masalah kontekstual peserta didik.
\end{abstract}

Kata Kunci: Problem Based Learning, Masalah Kontekstual, SPLTV

\section{PENDAHULUAN}

Saat ini, proses pembelajaran yang berpusat pada guru (teacher-center) masih banyak diterapkan oleh para guru di kelas. Pembelajaran yang demikian ternyata lebih mementingkan hasil daripada proses pembelajaran itu sendiri, sehingga pembelajaran terkesan monoton. Pada hakikatnya, proses pembelajaran yang berpusat pada guru sebenarnya tidak ada masalah, yang penting dalam penerapannya, guru tetap melibatkan peserta didik agar dapat selalu aktif dalam proses pembelajaran matematika. Namun, yang perlu diperhatikan guru harus bisa menyelenggarakan proses pembelajaran secara variatif.

Guru selalu menerapkan metode pembelajaran yang dapat mendorong peserta didik untuk dapat aktif dan semangat dalam mengikuti proses pembelajaran. Guru perlu menerapkan suatu model pembelajaran yang dapat membantu peserta didik untuk memahami materi ajar dan aplikasi serta relevansinya dalam kehidupan sehari-hari.

Berdasarkan pengamatan yang telah dilakukan oleh tim guru di kelas X-IPA SMA Islam Hasyim Asyari Batu, dapat diketahui bahwa terdapat beberapa permasalahan dalam pembelajaran di kelas tersebut, diantaranya guru cenderung sering melakukan metode ceramah dengan memanfaatkan buku LKPD sepanjang pembelajaran berlangsung, dan banyak peserta didik yang masih sulit memahami materi pelajaran matematika. Hal ini dapat terlihat saat peserta didik diberikan pertanyaan oleh guru, hanya beberapa peserta didik saja yang mampu menjawab pertanyaan, jawabannya pun masih terkesan seadanya dengan membaca kembali tulisan atau penjelasan yang ada di buku LKPD tanpa menggunakan analisis ataupun memahami masalah yang ditanyakan. Adanya permasalahan tersebut mengakibatkan hasil belajar peserta didik menjadi rendah.

Atas dasar permasalahan yang terjadi di kelas X-IPA SMA Islam Hasyim Asyari Batu, perlu dan penting menyelenggarakan pembelajaran matematika yang dapat membangkikan dan meningkatkan semangat belajar peserta didik. Dalam penelitian ini, peneliti menerapkan Problem Based Learning untuk meningkatkan kemampuan pemecahan masalah kontekstual bagi peserta didik kelas X-IPA SMA Islam Hasyim Asyari Batu pada materi Sistem Persamaan Linear Tiga Variabel (SPLTV).

Margetson dalam Rusman (2010) mengatakan bahwa Model Pembelajaran Berbasis Masalah (Problem Based Learning) membantu untuk meningkatkan perkembangan keterampilan belajar sepanjang hayat dalam pola pikir yang terbuka, reflektif, kritis, dan belajar aktif, serta memfasilitasi keberhasilan memecahkan masalah, komunikasi, kerja kelompok, dan keterampilan interpersonal dengan lebih baik dibanding model lain.

Muslimin dalam Utami (2011) mengatakan bahwa pembelajaran berdasarkan masalah (problem based learning) adalah suatu model untuk membelajarkan peserta didik untuk mengembangkan keterampilan berfikir dan keterampilan memecahkan masalah, belajar peranan orang dewasa yang otentik serta menjadi pelajar mandiri. Pembelajaran berdasarkan masalah tidak dirancang untuk 
membantu guru memberikan informasi yang sebanyakbanyaknya kepada peserta didik (Fitriatien, 2019b), akan tetapi pembelajaran berbasis masalah dikembangkan untuk membantu peserta didik mengembangkan kemampuan berpikir, pemecahan masalah dan keterampilan intelektual(Fitriatien, 2019a), belajar berbagai peran orang dewasa melalui pelibatan mereka dalam pengalaman nyata dan menjadi pembelajaran yang mandiri .

Berdasarkan beberapa pendapat ahli di atas, maka dapat disimpulkan bahwa Model Pembelajaran Berbasis Masalah (Problem Based Learning) adalah model pembelajaran yang diawali dengan pemberian masalah kepada peserta didik dimana masalah tersebut dialami atau merupakan pengalaman sehari-hari peserta didik, selanjutnya peserta didik menyeleseikan masalah tersebut secara mandiri untuk menemukan pengetahuan baru (Fitriatien, 2019c). Secara garis besar PBL terdiri dari kegiatan menyajikan suatu situasi masalah yang autentik dan bermakna kepada peserta didik serta memberikan kemudahan kepada mereka untuk melakukan penyelidikan dan inkuiri yang kemudian dengan melalui pemecahan masalah peserta didik belajar keterampilketerampilan yang lebih mendasar, sehingga kemampuan berpikir, memecahkan masalah dan keterampilan intelektual peserta didik meningkat

Pada model pembelajaran Problem Based Learning (PBL), peserta didik akan dibentuk dalam suatu kelompok-kelompok kecil dan peserta didik saling bekerjasama untuk memecahkan masalah kontekstual yang telah disajikan dalam Lembar Kerja Peserta Didik (LKPD). Penerapan model pembelajaran Problem Based Learning (PBL) ini dapat membuat peserta didik untuk aktif berdiskusi bersama anggota kelompok untuk memecahkan masalah kontekstual pada materi Sistem Persamaan Linear Tiga Variabel (SPLTV) dan dapat menemukan konsepnya secara mandiri.

Pada hakikatnya karakteristik Problem Based Learning (PBL), ini menciptakan pembelajaran yang menantang bagi peserta didik untuk memecahkan berbagai masalah yang dihadapi dengan menjalin kerjasama dengan peserta didik lain, dan guru hanya berperan sebagai fasilitator. Jadi pembelajaran berpusat pada peserta didik.

\section{METODE}

Penelitian ini menggunakan rancangan penelitian tindakan kelas yang terdiri dari dua siklus. Setiap siklus terdiri dari 4 (empat) tahapan, yaitu: perencanaan, pelaksanaan, observasi dan refleksi. Penelitian ini bertujuan untuk menerapkan Problem Based Learning untuk meningkatkan kemampuan pemecahan masalah kontekstual bagi peserta didik kelas X-IPA SMA Islam
Hasyim Asyari Batu pada materi Sistem Persamaan Linear Tiga Variabel (SPLTV).

Subjek Penelitian ini dilaksanakan di SMA Islam Hasyim Asyari Batu, dan subjek penelitian peserta didik kelas X IPA Tahun Pelajaran 2018/2019 terdiri dari 24 peserta didik, yang dilaksanakan pada bulan September 2018 sampai dengan Oktober 2018. Penelitian ini dilaksanakan dalam 2 siklus pembelajaran. Tindakan pendahuluan dalam penelitian ini adalah mengadakan tes pendahuluan untuk mengetahui hasil belajar peserta didik.

Setelah dilaksanakannya pembelajaran menggunakan Problem Based Learning, peserta didik diberi tes akhir I untuk mengetahui ketuntasan hasil belajar peserta didik dan digunakan sebagai acuan perbaikan untuk melaksanakan siklus II. Setelah dilaksanakan siklus II, peserta didik diberi tes Akhir II untuk mengetahui ketuntasan hasil belajar peserta didik dan akan dijadikan bahan refleksi dan evaluasi pelaksanaan tindakan pada siklus II.

Untuk menghitung ketuntasan hasil belajar peserta didik setelah penerapan Problem Based Learning dinyatakan sebagai berikut: (a) ketuntasan perorangan, seorang peserta didik dikatakan tuntas apabila telah mencapai nilai $\geq 70$ dari nilai maksimal 100. (b) ketuntasan klasikal, suatu kelas dikatakan tuntas apabila terdapat minimal $75 \%$ yang telah mencapai nilai $\geq 70$ dari nilai maksimal 100 .

\section{HASIL DAN PEMBAHASAN}

Penelitian ini dilaksanakan menggunakan dua siklus. Penerapan pembelajaran Problem Based Learning untuk meningkatkan kemampuan pemecahan masalah kontekstual bagi peserta didik kelas X-IPA SMA Islam Hasyim Asyari Batu pada materi Sistem Persamaan Linear Tiga Variabel (SPLTV) berjalan dengan baik, peserta didik termotivasi dan tertarik dalam mengikuti pelajaran sehingga aktivitas peserta didik cukup kondusif di dalam kelas. Peneliti dibantu oleh observer (teman sejawat) dalam melaksanakan pembelajaran.

Melalui kegiatan pembelajaran menggunakan model Problem Based Learning yang dipadukan dengan metode pendekatan saintifik yang menuntun peserta didik untuk mengamati (membaca) permasalahan, menuliskan penyelesaian, dan mempresentasikan hasilnya di depan kelas, peserta didik dapat menginterpretasi sistem persamaan linier tiga variabel dari masalah kontekstual.

Dalam pembelajaran peserta didik belajar dalam kelompok. Guru membagi peserta didik menjadi 4 (empat) kelompok. Masing-masing kelompok terdiri atas 6 (enam) peserta didik. Setelah peserta didik menempati posisinya, guru LKPD (Lembar Kerja Peserta Didik) yang telah disiapkan oleh guru LKPD (Lembar Kerja Peserta Didik) 
yang telah disiapkan oleh guru dan memberikan ulasan umum materi, kemudian Guru memberikan kesempatan kepada peserta didik untuk mengidentifikasi sebanyak mungkin pertanyaan yang berkaitan materi yang telah diberikan dan akan dijawab melalui kegiatan belajar.

Berikutnya, guru menjelaskan kepada peserta didik cara pengerjaan LKPD dan meminta peserta didik untuk berdiskusi dan bekerja sama dengan anggota kelompoknya, untuk memecahkan persoalan yang ada dalam LKPD. LKPD ini diberikan untuk mempermudah peserta didik mencapai tujuan pembelajaran dengan menerapkan Problem Based Learning. Dalam kelompok peserta didik diharapkan untuk memahami materi dan menyelesaikan masalah yang terkait membuat model matematika dari masalah sehari-hari yang berkaitan dengan sistem persamaan linier tiga variabel dan menyelesaikan model matematika dari masalah sehari-hari yang berkaitan dengan sistem persamaan linier tiga variabel.

Kegiatan selanjutnya yaitu mempresentasikan hasil kerja belajarnya di masing-masing kelompok. Aktivitas ini dapat melatih peserta didik untuk berani tampil di depan teman-temannya dalam mempresentasikan hasil diskusinya dan berlatih untuk menyampaikan argumen hasil diskusinya. Pada akhir pembelajaran siklus I, dilaksanakan tes akhir. Pada pembelajaran yang pertama masih ada beberapa kendala. Hal ini disebabkan peserta didik belum terbiasa dengan metode pembelajaran Problem Based Learning. Pada siklus pertama hasil belajar peserta didik belum memenuhi kriteria yang diharapkan. Sehingga peneliti melanjutkan pada siklus berikutnya.

Siklus II dilaksanakan dengan baik, proses pembelajaran dilakukan sama dengan siklus I. Pada siklus II peserta didik sudah memiliki kemampuan pemahaman materi dengan baik. Peserta didik juga sudah terbiasa belajar dalam kelompok. Hal tersebut terbukti dengan meningkatnya hasil belajar peserta didik. Pada siklus II hasil belajar peserta didik mengalami peningkatan dan sudah memenuhi Kriteria Ketuntasan Minimal (KKM), sehingga tidak perlu melaksanakan siklus berikutnya. Dalam Problem Based Learning, peserta didik didorong untuk belajar menyelesaikan masalah kontekstual. Peserta didik belajar melalui keterlibatan aktif dengan konsepkonsep dan prinsip-prinsip dalam memecahkan masalah, dan guru mendorong peserta didik untuk mendapatkan pengalaman dengan melakukan kegiatan yang memungkinkan peserta didik dapat menemukan penyelesaian masalah kontekstual, bukan memberi tahu tetapi memberikan kesempatan atau dengan berdialog agar peserta didik menemukan sendiri.

Aktivitas peserta didik dalam pembelajaran yang diamati dalam penelitian ini yaitu meliputi kemampuan peserta didik dalam: mengumpulkan dan mengolah informasi, menyelesaikan masalah kontekstual, mempresentasikan hasil pemecahan masalah, mengkomunikasikan dan mengasosiasikan hasil presentasi. Hasil observasi aktivitas peserta didik dapat dilihat pada tabel berikut:

Tabel 1. Persentase Aktivitas Peserta Didik

\section{No Aktivitas Peserta Didik Siklus I (\%)Siklus II(\%)}

\begin{tabular}{|c|c|c|c|}
\hline 1. & $\begin{array}{ll}\text { Mengumpulkan } & \text { dan } \\
\text { mengolah informasi } & \end{array}$ & 80,75 & 88,63 \\
\hline & Menyelesaikan masalah & & \\
\hline 2. & kontekstual & 72,85 & 85,78 \\
\hline 3 & $\begin{array}{l}\text { Mempresentasikan hasil } \\
\text { pemecahan masalah }\end{array}$ & 65,05 & 74,68 \\
\hline 4 & $\begin{array}{l}\text { Mengkomunikasikan dan } \\
\text { mengasosiasikan hasil } \\
\text { presentasi }\end{array}$ & 60,57 & 72,25 \\
\hline
\end{tabular}

Hasil observasi aktivitas peserta didik pada siklius I, yaitu: aktivitas mengumpulkan dan mengolah informasi $80,75 \%$, aktivitas menyelesaikan masalah kontekstual $72,85 \%$, aktivitas mempresentasikan hasil pemecahan masalah 65,05\% dan aktivitas Mengkomunikasikan dan mengasosiasikan hasil presentasi $60,57 \%$, sehingga diperoleh persentase aktivitas belajar secara klasikal sebesar $69,80 \%$. Sedangkan pada siklus yang II, aktivitas mengumpulkan dan mengolah informasi $88,63 \%$, aktivitas menyelesaikan masalah kontekstual $85,78 \%$, aktivitas mempresentasikan hasil pemecahan masalah $74,68 \%$ dan aktivitas mengkomunikasikan dan mengasosiasikan hasil presentasi $72,25 \%$, sehingga diperoleh persentase aktivitas belajar secara klasikal sebesar 80,33\%. Sehingga aktivitas peserta didik secara klasikal meningkat sebesar $10,53 \%$.

Dalam penelitian ini peserta didik diberikan 3 kali tes, yaitu tes pendahuluan (Pra Siklus), tes Akhir siklus I dan tes Akhir Siklus II. Bentuk soal dari masing-masing tes adalah tes uraian. Masing-masing tes terdiri atas empat soal, dengan skor minimal 0 dan skor maksimal 100. Hasil belajar peserta didik dalam kemampuan memecahkanmasalah kontekstual pada penelitian ini mengalami peningkatan. Hal tersebut dapat dilihat pada ketuntasan hasil belajar peserta didik yang ditunjukkan pada tabel berikut ini :

Tabel 2. Peningkatan Hasil Belajar Peserta Didik

\begin{tabular}{llccc}
\hline & & & $\begin{array}{c}\text { Siklus } \\
\text { I }\end{array}$ & $\begin{array}{c}\text { Siklus } \\
\text { II }\end{array}$ \\
\cline { 3 - 4 } No & Kategori Hasil Belajar & & & \\
& & Siklus & $(\%)$ & $(\%)$
\end{tabular}

Tuntas, memenuhi KKM $(\geq$
1. 70) dari
$56,5470,60$ 
Mustangin ${ }^{1}$, Abdul Halim Fathani ${ }^{2}$, Teguh Sugiharto ${ }^{3}$ : Penerapan Problem Based Learning untuk Meningkatkan Kemampuan Pemecahan Masalah Kontekstual bagi Peserta Didik Kelas X-IPA SMA Islam Hasyim Asy'ari Batu pada Materi Sistem Persamaan Linear Tiga Variabel

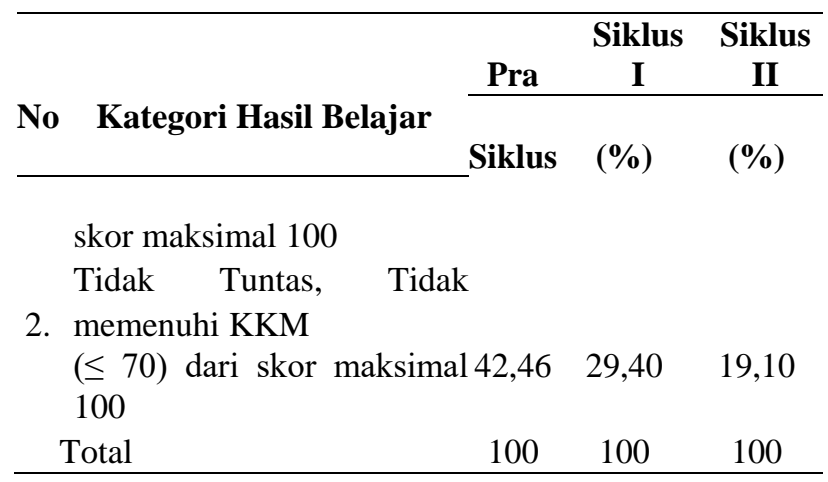

Berdasarkan tabel persentase hasil belajar peserta didik di atas, diketahui bahwa hasil belajar peserta didik yang tergolong dalam kategori tuntas pada tes pendahuluan hanya 56,54\% (17 Peserta didik), siklus I sebesar 70,60\% (20 Peserta didik) sedangkan pada siklus II mencapai 80,90\% (30 Peserta didik), dengan demikian kategori hasil belajar peserta didik yang tergolong tuntas mengalami peningkatan. Hasil belajar peserta didik yang tergolong dalam kategori tidak tuntas pada siklus I sebesar 29,40\% (13 Peserta didik) sedangkan pada siklus II sebesar 19,10\% (3 Peserta didik) dengan demikian kategori hasil belajar peserta didik yang tergolong tidak tuntas mengalami penurunan.

Penelitian ini adalah penelitian tindakan kelas yang bertujuan untuk mengetahui bagaimana penerapan Problem Based Learning, aktivitas peserta didik selama penerapan Problem Based Learning, dan bagaimana hasil belajar peserta didik selama proses pembelajaran dengan penerapan Problem Based Learning. Berdasarkan data yang diperoleh, maka akan dibahas penerapan pembelajaran, aktivitas peserta didik selama proses pembelajaran dan hasil belajar peserta didik selama penerapan Problem Based Learning. Penerapan Problem Based Learning berjalan dengan baik, meskipun ada beberapa hambatan yang dihadapi namun hambatan tersebut dapat diselesaikan pada pertemuan selanjutnya.

Pembelajaran yang diterapkan pada penelitian ini adalah pembelajaran melalui penerapan Problem Based Learning pada sub pokok bahasan menyelesaikan masalah kontekstual matematika melalui sistem persamaan linear tiga variabel. Penelitian ini dilaksanakan sebanyak 2 (dua) siklus. Dalam penerapan Problem Based Learning pada siklus 1 dapat dikatakan berjalan dengan lancar meskipun terdapat beberapa kendala diantaranya adalah sebagai berikut:

1) Pada awal pembelajaran agak sedikit ramai dalam mencari kelompoknya, bahkan ada yang kurang setuju dengan anggotanya dikarenakan kurang akrab.

2) Aktivitas peserta didik dalam berinovasi, presentasi dan bertanya masih rendah.
3) Beberapa peserta didik kurang teliti dalam menjawab soal sehingga banyak kesalahan yang terjadi.

4) Guru mempersilakan peserta didik untuk mempresentasikan hasil diskusinya namun banyak diantara mereka yang malu dan takut hal ini mungkin dikarenakan kebiasaan mereka pada kegiatan sebelumnya yang pasif dalam pembelajaran.

Kendala-kendala tersebut dapat diatasi pada siklus II, yaitu: (1) peserta didik sudah mulai menerima dan mulai akrab dengan aggota kelompoknya, (2) memberikan bimbingan dan motivasi yang dilakukan oleh peneliti mampu meningkatkan keaktifan peserta didik dalam belajar, hal ini diperoleh dari meningkatnya persentase dari setiap siklus, guru memberikan perpanjangan waktu agar peserta didik lebih teliti dalam menjawab soal latihan, dan (4) guru memberikan reward pada peserta didik agar peserta didik tidak lagi malu atau takut dalam melakukan presentasi.

\section{PENUTUP}

\section{Simpulan}

Berdasarkan hasil penelitian dan pembahasan yang telah diuraikan, maka dapat disimpulkan bahwa penerapan Problem Based Learning untuk meningkatkan kemampuan pemecahan masalah kontekstual bagi peserta didik kelas X-IPA SMA Islam Hasyim Asyari Batu berjalan dengan baik, peserta didik terlihat lebih antusias dan tertarik dalam mengikuti pelajaran. Dalam pembelajaran ini kegiatan pembelajarannya disusun sesuai dengan tahap-tahap dalam Problem Based Learning. Meskipun dalam pelaksanaannya masih terdapat sedikit hambatan pada pembentukan kelompok dan pada saat peserta didik disuruh presentasi. Namun, hal itu dapat diatasi dengan memberikan bimbingan dan motivasi yang lebih intensif beserta reward pada peserta didik Selain itu, penerapan Problem Based Learning untuk meningkatkan kemampuan pemecahan masalah kontekstual bagi peserta didik kelas X-IPA SMA Islam Hasyim Asyari Batu dapat meningkatkan keaktifan peserta didik dalam pembelajaran. Hal tersebut dapat ditunjukkan pada analisis aktivitas peserta didik dalam pembelajaran dengan penerapan Problem Based Learning. Untuk proses pemecahan masalah, penerapan Problem Based Learning dapat meningkatkan kemampuan pemecahan masalah kontekstual bagi peserta didik kelas X-IPA SMA Islam Hasyim Asyari Batu yang diperoleh dari persentase ketuntasan pada siklus I sebesar 69,80\% (tuntas) dan pada siklus II sebesar $80,33 \%$ (tuntas).

\section{Saran}

Guna keberlanjutan penelitian selanjutnya, meningkatkan kemampuan pemecahan masalah kontekstual bagi peserta didik dapat dilakukan melalui 
kolaborasi dengan guru di sekolah dengan menerapkan model atau metode pembelajaran yang sesuai dengan materi matematika.

\section{DAFTAR PUSTAKA}

Amir, M. Taufiq. 2009. Inovasi Pendidikan Melalui Problem Based Learning. Jakarta: Kencana Prenada Media Group.

Duch, J.B. 1995. What is Problem Based Learning? (online).

Tersedia:

http://www.udel.edu/pbl/cte/jan95-what.html. (diakses 1 Oktober 2018).

Fitriatien, S. R. (2019a). Analisis Kesalahan Dalam Menyelesaikan Soal Cerita Matematika Berdasarkan Newman.

JIPMat. https://doi.org/10.26877/jipmat.v4i1.3550

Fitriatien, S. R. (2019b). Error description of the first year student in aljabar problems. Math Didactic: Jurnal Pendidikan Matematika. https://doi.org/10.33654/math.v5i2.655

Fitriatien, S. R. (2019c). HISTOGRAM: Jurnal Pendidikan Matematika. 3.

Laksono, S \& Siswono, T.Y.E. 2018. Penelitian Tindakan Kelas. Bandung: Remaja Rosdakarya.

Nasution, S, 2000, Penelitian Ilmiah. Jakarta: Penerbit Bumi Aksara.

Rusman. 2010. Model-model Pembelajaran Mengembangkan Profesionalisme Guru. Bandung: Mulia Mandiri Pers.

Suyanto dan Jihad. 2013. Menjadi Guru Profesional Strategi Meningkatkan Kualifikasi dan Kualitas Guru di Era Global. Jakarta: Esensi Erlangga Group.

Wardani, I.G.A.K, dkk. 2006. Penelitian Tindakan Kelas. Jakarta: Universitas Terbuka. 
Mustangin $^{1}$, Abdul Halim Fathani², Teguh Sugiharto ${ }^{3}$ : Penerapan Problem Based Learning untuk Meningkatkan Kemampuan Pemecahan Masalah Kontekstual bagi Peserta Didik Kelas X-IPA SMA Islam Hasyim Asy'ari Batu pada Materi Sistem Persamaan Linear Tiga Variabel 